Supporting Information for the communication entitled

\title{
Distinct Dynamic Behaviors of Water Molecules in Hydrated Pores
}

by

Martín Febles, ${ }^{\dagger}$ Natalia Pérez-Hernández, ${ }^{\dagger}$ Cirilo Pérez, ${ }^{\dagger}$ Matías L. Rodríguez, ${ }^{\dagger}$ Concepción Foces-Foces, ${ }^{\perp}$ María Victoria Roux, ${ }^{\perp}$ Ezequiel Q. Morales, ${ }^{\ddagger}$ Gerd Buntkowsky, ${ }^{\#}$ Hans-Heinrich Limbach, ${ }^{\S}$ and Julio D. Martín.* ${ }^{*}$

${ }^{\dagger}$ Instituto de Bioorgánica, Universidad de La Laguna-CSIC, Ctra. Vieja de La Esperanza 2, 38206 La Laguna, Tenerife, Spain, ${ }^{\dagger}$ Instituto de Investigaciones Químicas, CSIC, Avda. Américo Vespucio s/n, 41092 Seville, Spain, ${ }^{\perp}$ Instituto de Química-Física Rocasolano, CSIC, Serrano 119, 28006 Madrid, Spain, \#Institut für Physikalische Chemie, Friedrich-Schiller Universität, Helmholtzweg 4, D-07743 Jena, Germany and ${ }^{\S}$ Institut für Chemie, Freie Universität Berlin, Takusstr. 3, D-14195 Berlin, Germany

$1 \underline{\text { Solid state NMR results on a tubular structure formed by }( \pm) \mathbf{1} \cdot 2 \mathrm{H}_{2}} \underline{\mathrm{O}} \quad \mathrm{S} 2$

1.1 ${ }^{1} \mathrm{H}$ and ${ }^{2} \mathrm{H}$ MAS NMR experiments $\quad$ S2

1.2 Solid State Static ${ }^{2} \mathrm{H}$ NMR results $\quad$ S3

1.3 Kinetics of the deuteration process by Solid State Static ${ }^{2} \mathrm{H}$ NMR $\quad$ S4

1.4 Experimental $\quad$ S5

1.4.1 MAS NMR experiments $\quad$ S5

1.4.2 Solid State Static ${ }^{2} \mathrm{H}$ NMR experiments $\quad$ S6

2 DSC and TG results for compounds $( \pm) \mathbf{1} \cdot 2 \mathrm{H}_{2} \underline{\mathrm{O} \text { and }( \pm) 2 \cdot 2 \mathrm{H}_{2}} \underline{\mathrm{O}}$

2.1 DSC results for compound $( \pm) \mathbf{1} \cdot 2 \mathrm{H}_{2} \mathrm{O}$

2.2 DSC results for compound $( \pm) 2 \cdot 2 \mathrm{H}_{2} \underline{\mathrm{O}} \quad \mathrm{S} 7$

2.3 Loss of water content of $( \pm) \mathbf{1} \cdot 2 \mathrm{H}_{2} \mathrm{O}$ and $( \pm) \mathbf{2} \cdot 2 \mathrm{H}_{2} \mathrm{O}$ (DSC /TG ) S7

2.4 Experimental $\quad \mathrm{S} 8$

2.4.1 DSC Experiments $\quad$ S8

2.4.2 TG Experiments $\quad$ S9

3 Analytical Data for Compound $( \pm) 2 \quad$ S9

3.1 Experimental procedure and spectroscopic and physical data $\quad$ S9

3.2 Crystal structure data for $( \pm) 2 \cdot 2 \mathrm{H}_{2} \mathrm{O}$ at $170 \mathrm{~K} \quad \mathrm{~S} 10$ 
1 Solid state NMR results on tubular structure formed by $( \pm) \mathbf{1} \cdot 2 \mathrm{H}_{2} \underline{\mathrm{O}}$

\section{1 ${ }^{1} \mathrm{H}$ and ${ }^{2} \mathrm{H}$ MAS NMR experiments}

A series of ${ }^{1} \mathrm{H}$ MAS experiments $(600 \mathrm{MHz}$, spin rate $=24 \mathrm{kHz})$ were performed using differently treated samples of $( \pm) \mathbf{1} \cdot 2 \mathrm{H}_{2} \mathrm{O}$

Crystals containing the tubular structures gave rise to the spectrum shown in figure 1a, where the acidic and alcoholic mobile proton sites can be identified. In contrast, no structural water signal is observed due to its motion rate under these conditions. The spectrum of the same sample submitted to high vacuum ${ }^{1}$ exhibits a greater distribution of signals because of structural changes in the pore-like assembly caused by the removal of water (figure 1b). In agreement with results obtained by calorimetric experiments, the presence of water is necessary for the tubular structure to be held together.

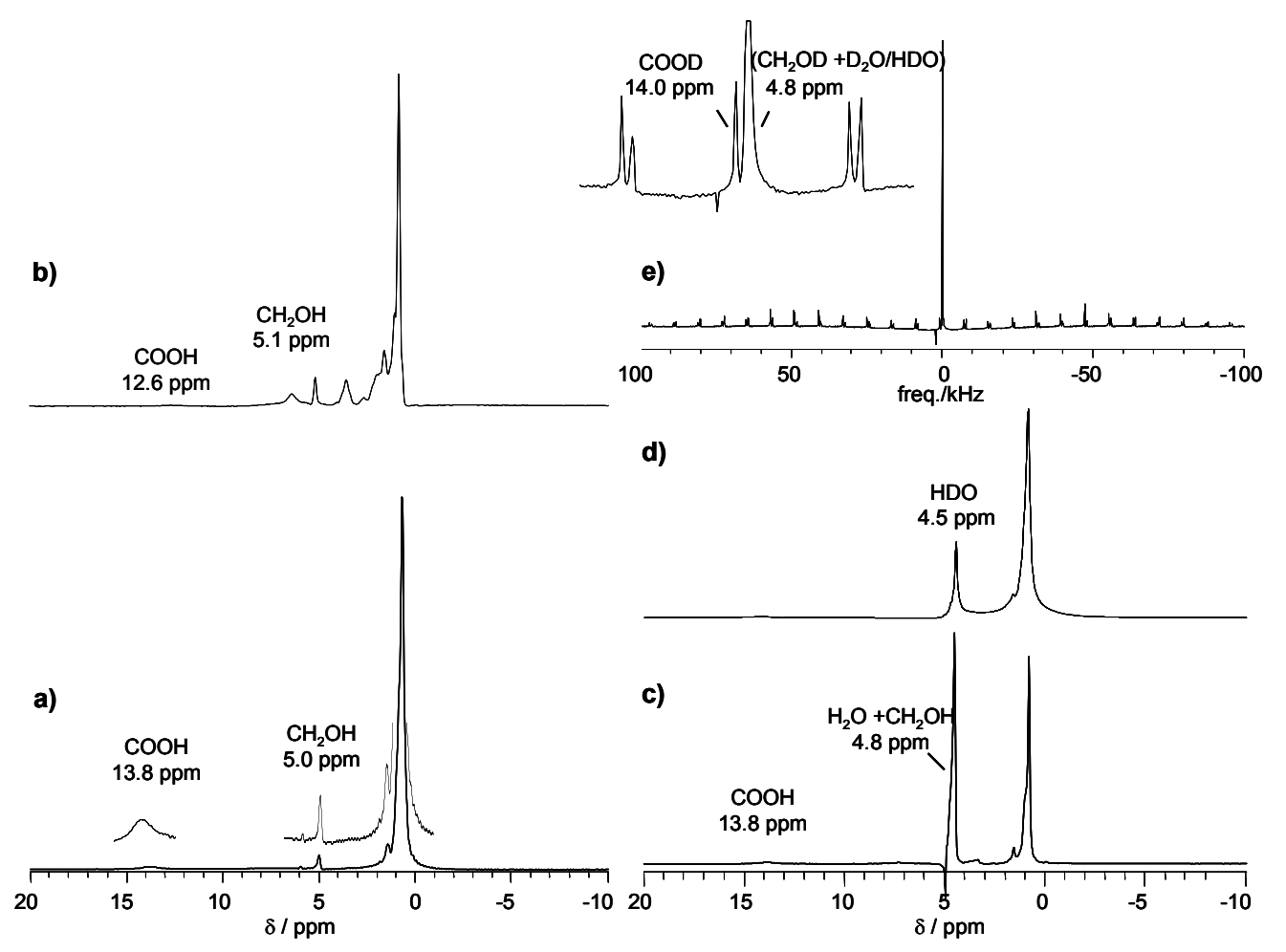

Figure 1: a) ${ }^{1} \mathrm{H}$ MAS NMR spectrum of a tubular compound formed by $( \pm) \mathbf{1} \cdot 2 \mathrm{H}_{2} \mathrm{O}$ with expansion of alcoholic and acidic ${ }^{1} \mathrm{H}$ signals. b) ${ }^{1} \mathrm{H}$ MAS NMR spectrum of $( \pm) \mathbf{1} \cdot 2 \mathrm{H}_{2} \mathrm{O}$ after being submitted to high vacuum overnight. c) ${ }^{1} \mathrm{H}$ MAS NMR spectrum of $( \pm) \mathbf{1} \cdot 2 \mathrm{H}_{2} \mathrm{O}$ after exposure to $\mathrm{H}_{2} \mathrm{O}$ vapor. d) ${ }^{1} \mathrm{H}$ MAS NMR spectrum of $( \pm) \mathbf{1} \cdot 2 \mathrm{H}_{2} \mathrm{O}$ after exposure to $\mathrm{D}_{2} \mathrm{O}$ vapor. e) Complementary ${ }^{2} \mathrm{H}$ spectrum of sample d) with expansion of central band.

Exposure of $( \pm) \cdot 2 \mathrm{H}_{2} \mathrm{O}$ crystals to $\mathrm{H}_{2} \mathrm{O}$ or $\mathrm{D}_{2} \mathrm{O}$ vapor does not alter the pore structure, as inferred from the known resulting ${ }^{1} \mathrm{H}$ spectra of the treated samples (figures $1 \mathrm{c}$ and 1d). Furthermore, it results in the acquisition of a large number of water

\footnotetext{
${ }^{1}$ The sample was exposed to $10^{-7}$ mbar overnight.
} 
molecules exhibiting a high degree of mobility inside the pore and giving rise to sharp and intense signals. The isotropic signal in the complementary ${ }^{2} \mathrm{H}$ spectrum (spin rate $=$ $12 \mathrm{kHz}$ ), of the sample exposed to $\mathrm{D}_{2} \mathrm{O}$ vapor (figure 1e) indicates bulk-water behavior ${ }^{2}$ of these water molecules.

By means of exposing the sample to gaseous $\mathrm{D}_{2} \mathrm{O}$ at a lower vapor pressure, the mobile proton sites of the tubular structure can be partially deuterated without the entry of a great number of water molecules (figures $2 \mathrm{a}$ and $2 \mathrm{~b}$ ).
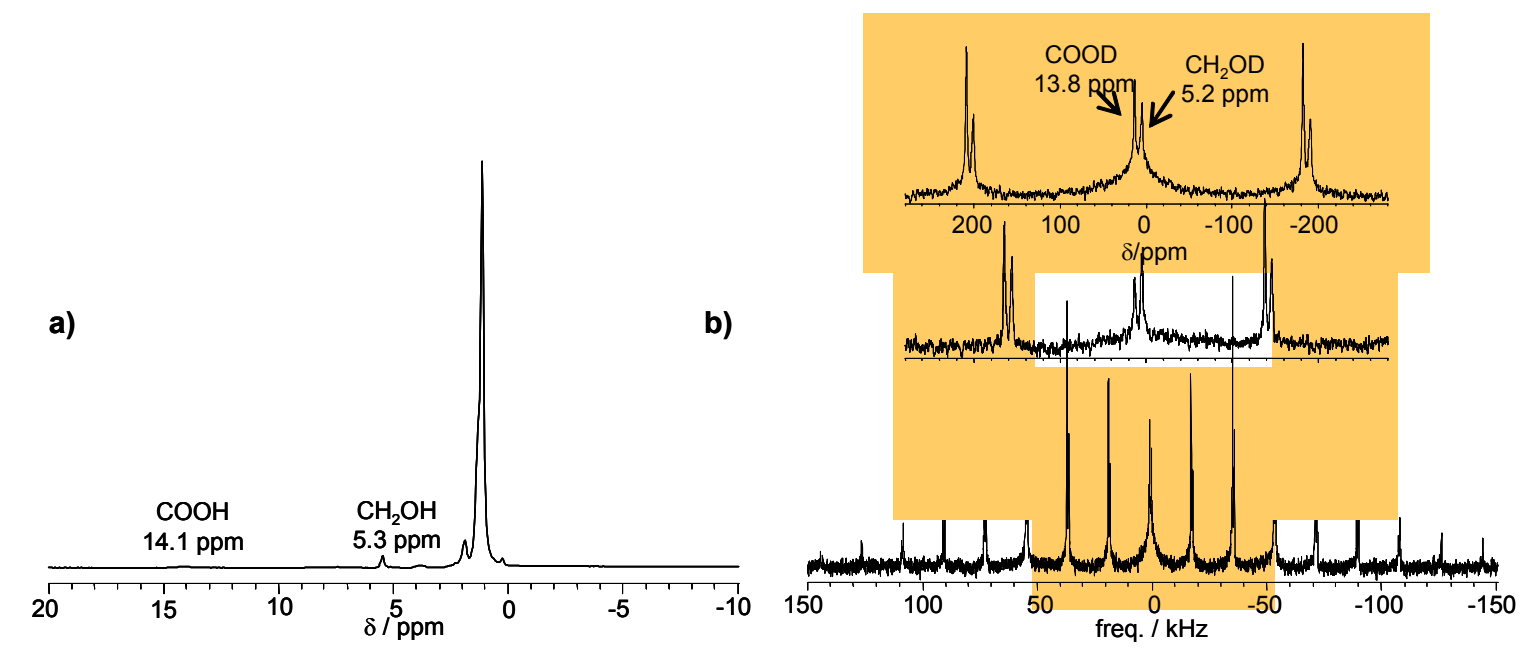

Figure 2: a) ${ }^{1} \mathrm{H}$ MAS NMR spectrum of crystals of $( \pm) \mathbf{1} \cdot 2 \mathrm{H}_{2} \mathrm{O}$ exposed to $\mathrm{D}_{2} \mathrm{O}$ vapor, showing the expected appearance for the pore-forming sample. b) ${ }^{2} \mathrm{H}$ MAS NMR spectrum of the same sample with expansion of central bands for a clear view of the deuterated alcoholic and acidic mobile sites.

\subsection{Solid State Static ${ }^{2} \mathrm{H}$ NMR results}

In a row of static ${ }^{2} \mathrm{H} \mathrm{NMR}^{3}$ experiments $(300 \mathrm{MHz})$, a sample of $( \pm) \mathbf{1} \cdot 2 \mathrm{H}_{2} \mathrm{O}$ treated in such a way is used to verify the presence of structural water molecules moving across their sites in the walls of the pore, and thus not observed in any of the above -mentioned spectra. At room temperature, only a small fraction of water molecules in the form of clusters or "mini-droplets" inside the pore can be observed as low intensity, and, in some case, isotropic signals. As expected, the largest water amount is not observable until the temperature is lowered to $223 \mathrm{~K}$. The incorporation of the structural water signal to the spectrum at low temperatures produces a great increase in the alcoholic OD signal intensity, which showed a 1:1 ratio when compared to the acidic COOD signal

\footnotetext{
${ }^{2}$ The intense and sharp line in the central band of the ${ }^{2} \mathrm{H}$ spectrum does not appear in the spinning sidebands, indicating isotropic behavior of the $\mathrm{D}_{2} \mathrm{O}$ molecules.

${ }^{3}$ See combined static ${ }^{2} \mathrm{H}$ NMR and calorimetric experiments for identifying water molecules exhibiting different motion rates: (a) Su, C.-Y.; Goforth, A.M.; Smith, M.D.; Pellechia, P.J.; zur Loye, H.-C. J. Am. Chem. Soc. 2004, 126, 3576-3586; (b) Cheruzel, L. E.; Pometun, M. S.; Cecil, M.R.; Mashuta, M. S.; Wittebort, R.J.; Buchanan, R.M.; Angew. Chem. Int. Ed. 2003, 42, 5452-5455.
} 
intensity at room temperature ${ }^{4}$ (figures $3 \mathrm{a}$ and $3 \mathrm{~b}$ ). This change of the structural water motion is observed for several samples treated in the same way, and takes place lineally in the expected temperature interval according to DSC experiments (see figure $3 \mathrm{c}$ ). ${ }^{5}$

Besides, the broadening of the signals corresponding to the small water fraction in the form of clusters or mini-droplets ${ }^{6}$ shows the temperature influence on the motion of these water molecules.
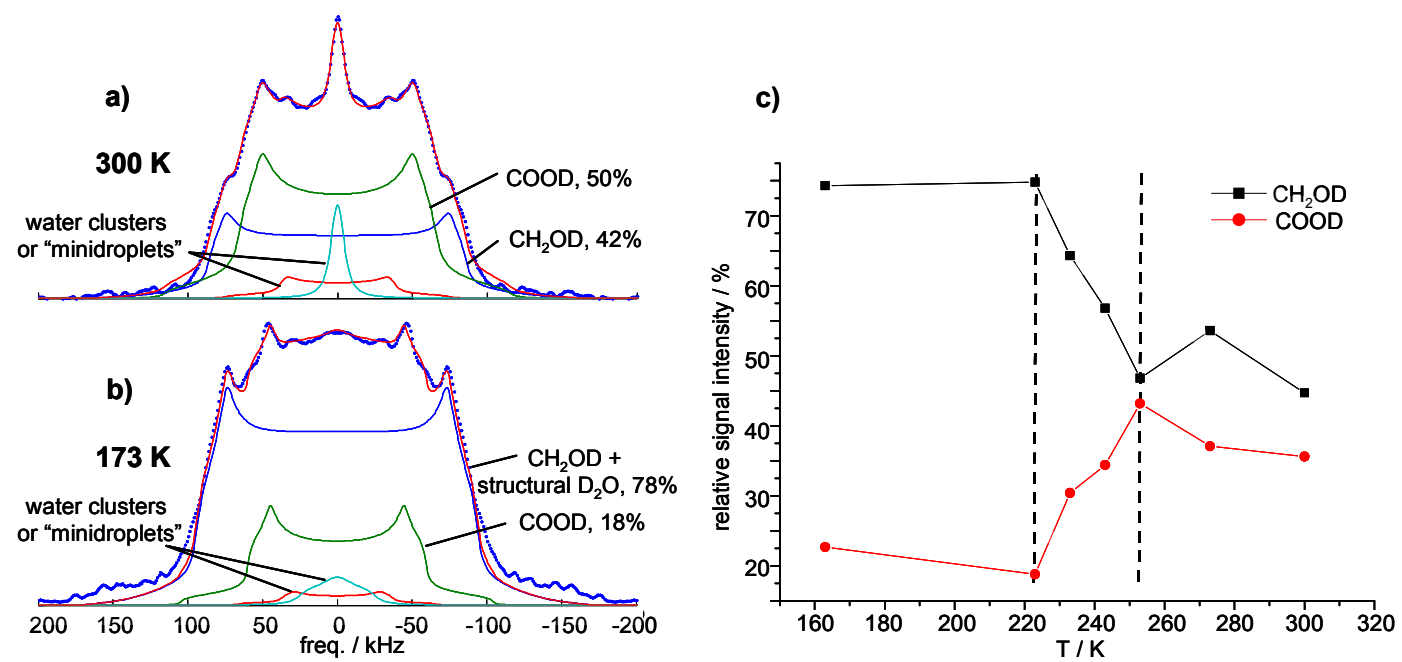

Figure 3: a) and b) Superposition of static ${ }^{2} \mathrm{H}$ NMR spectra and simulations of individual signals at $300 \mathrm{~K}$ and $173 \mathrm{~K}$ respectively. Assignment of deuterated water, alcoholic and acidic functions as well as relative intensity percentages are depicted. c) Graph with representation of $\mathrm{CH}_{2} \mathrm{OD}$ and $\mathrm{COOD}$ relative signal intensities versus temperature for a series of static ${ }^{2} \mathrm{H}$ NMR experiments. The linear change of intensities takes place in the enhanced temperature interval.

\subsection{Kinetics of the deuteration process followed by Solid State Static ${ }^{2} \mathrm{H}$ NMR}

The sample is exposed for 15 minutes, 30 minutes, $1 \mathrm{~h}$ and $2.5 \mathrm{~h}$ to $\mathrm{D}_{2} \mathrm{O}$ vapor. Only after $2.5 \mathrm{~h}$ is there a visible deuterium signal. The same sample is afterwards exposed for $11 \mathrm{~h}$, thus $13.5 \mathrm{~h}$ altogether. During this time, the sample undergoes a weight increase of $3.2 \%$. The spectra and the simulations are shown in figure 4.

\footnotetext{
${ }^{4}$ Signals have been assigned according to the known ${ }^{2} \mathrm{H}$ MAS spinning sideband pattern as well as considering hydrogen bond strengths and distances correlated to quadrupolar coupling constants: (a) Brunner, E.; Sternberg, U., Progr. NMR. Spect. 1998, 32, 21-57. (b) Chiba, T. J. Chem. Phys. 1964, 41, 1352-1358. (c) Chiba, T.; Soda, G. Bull. Chem. Soc. Jpn. 1971, 44, 1703-1705. (d) Berglund, B.; Vaughan, R.W. J. Chem. Phys. 1980, 73, 2037-2043. (e) Seliger, J.; Žagar, V.; Blinc, R. Chem. Phys. Lett. 1984, 104, 277-278.

${ }^{5}$ This methodology has been used to study the motion of water in ice and allows estimating correlation times of microseconds for the structural water molecules in our sample: Wittebort, R.J.; Usha, M.G.; Ruben, D.J.; Wemmer, D.E., Pines, A. J. Am. Chem. Soc. 1988, 110, 5668-5671.

${ }^{6}$ For examples of the NMR characterization of water molecules with different motion rates, see: (a) Klug, C.A.; Lee, P.L.; Lee, I.-S. H.; Kreevoy, M.M.; Yaris, R.; Schaefer, J. J. Phys. Chem. B 1997, 101, 80868091. (b) Grünberg, B.; Emmler, T.; Gedat, E.; Shenderovich, I.; Findenegg, G.H.; Limbach, H.-H.; Buntkowsky, G. Chem. Eur. J. 2004, 10, 5689-5696.
} 


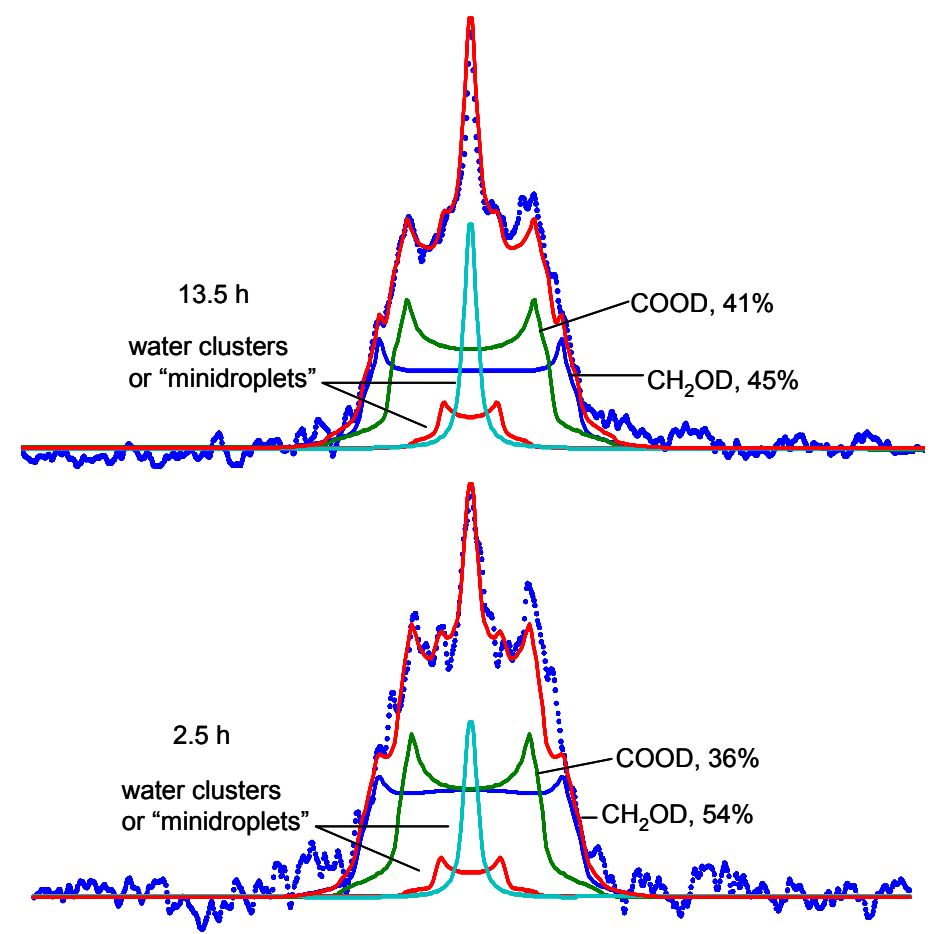

Figure 4: Room temperature static ${ }^{2} \mathrm{H}$ spectrum and simulation of sample exposed for $2.5 \mathrm{~h}$ (down) and for $13.5 \mathrm{~h}$ (up) to $\mathrm{D}_{2} \mathrm{O}$. Signal intensities are depicted. Note how after $13.5 \mathrm{~h}$ the OD and COOD positions are already deuterated to the same extent and have the same appearance as the spectra recorded after days of exposure.

\subsection{Experimental}

\subsubsection{MAS NMR experiments}

For the experiments with the "standard" $( \pm) \mathbf{1} \cdot 2 \mathrm{H}_{2} \mathrm{O}$ sample, around $10 \mathrm{mg}$ of crystals grown from a $\mathrm{CCl}_{4} / \mathrm{n}$-hexane interface were simply introduced in the rotor. In the case of samples exposed to $\mathrm{H}_{2} \mathrm{O}$ or $\mathrm{D}_{2} \mathrm{O}$ vapor, and samples submitted to vacuum, the substance was rapidly introduced in the rotor immediately prior to the measurement. Exposure to $\mathrm{H}_{2} \mathrm{O}$ or $\mathrm{D}_{2} \mathrm{O}$ was achieved by means of introducing the sample in an open eppendorf which in turn was placed in a small desiccator containing approximately 10 $\mathrm{ml}$ of $\mathrm{H}_{2} \mathrm{O}$ or $\mathrm{D}_{2} \mathrm{O}$. The whole system was kept at $40{ }^{\circ} \mathrm{C}$ over several days. In all cases a Varian $600 \mathrm{MHz}$ Infinity Plus spectrometer was used equipped with Spinsight Software (version 4.3.2), and a $3.2 \mathrm{~mm}$ HX-T3 Chemmagnetics probehead. The spin rate was 24 $\mathrm{kHz}$ in the ${ }^{1} \mathrm{H}$ experiments (stabilized by the spectrometer), a spin-echo pulse sequence (echo delay $=833 \mu \mathrm{s}=20$ rotor cycles, $\mathrm{ns}=512$, pulse delay $=6 \mathrm{~s}$ ) was used, and TSP was the reference for the chemical shift. Even using a spin-echo sequence, a signal corresponding to the empty rotor was observed in the spectra. For this reason, all measurements had to be completed with a parallel experiment of the empty rotor, and its 
signal was afterwards subtracted to obtain the spectrum only with the actual sample signals.

For typical ${ }^{2} \mathrm{H}$ experiments, spin rates of 8 to $18 \mathrm{kHz}, 1$ pulse experiments $(\mathrm{pd}=$ $6 \mathrm{~s}, \mathrm{~ns}=12000$ ), and deuterated polystyrene for the chemical shift reference were used.

\subsubsection{Solid State Static ${ }^{2} \mathrm{H}$ NMR experiments}

In this case approximately $150 \mathrm{mg}$ of substance were introduced in an NMR tube which was sealed $1.5 \mathrm{~cm}$ above the top of the substance, in order to avoid exchange of the deuterated sample with environmental $\mathrm{H}_{2} \mathrm{O}$. The static ${ }^{2} \mathrm{H}$ experiments were performed using a home built $5 \mathrm{~mm}{ }^{2} \mathrm{H}-\mathrm{NMR}$ probe. The probe is placed in a dynamic Oxford CF1200 helium flow cryostat. The sample temperature was controlled employing an Oxford ITC 503 temperature controller. Spin-echo experiments with optimized parameters for a deuterated polystyrene sample were performed, using pulse delays between $1 \mathrm{~s}$ and $20 \mathrm{~s}$ (increasing the delay when lowering temperature), and using 5000 accumulations (for long pulse delays) and 50000 accumulations (for short pulse delays).

\section{$2 \quad$ DSC and TG results for compounds $( \pm) \mathbf{1} \cdot 2 \mathrm{H}_{2} \underline{\mathrm{O}}$ and $( \pm) 2 \cdot 2 \mathrm{H}_{2} \underline{\mathrm{O}}$}

\subsection{DSC results for compound $( \pm) \mathbf{1} \cdot 2 \mathrm{H}_{2} \underline{\mathrm{O}}$}

Table 1: DSC experiment performed on a $( \pm) \mathbf{1} \cdot 2 \mathrm{H}_{2} \mathrm{O}$ sample.

\begin{tabular}{|c|c|c|c|c|c|c|c|}
\hline process & $\begin{array}{c}\text { rate } \\
\mathrm{K} / \mathrm{min}\end{array}$ & \multicolumn{3}{|c|}{ modification 1 } & \multicolumn{3}{c|}{ modification 2 } \\
\hline & & $\begin{array}{c}\text { temp.interval } \\
T / \mathrm{K}\end{array}$ & $\begin{array}{c}T_{\text {peak }} \\
\mathrm{K}\end{array}$ & $\begin{array}{c}\Delta H^{\circ} \\
\mathrm{J} / \mathrm{g}\end{array}$ & $\begin{array}{c}\text { temp.interval } \\
T / \mathrm{K}\end{array}$ & $\begin{array}{c}T_{\text {peak }} \\
\mathrm{K}\end{array}$ & $\begin{array}{c}\Delta H^{\circ} \\
\mathrm{J} / \mathrm{g}\end{array}$ \\
\hline $1^{\text {st }}$ cooling & 5 & & & & & & \\
\hline $1^{\text {st }}$ heating & 10 & $197.1 \rightarrow 273.0$ & 246.4 & 5.4 & $273.0 \rightarrow 292.2$ & 279.8 & 0.5 \\
\hline $2^{\text {nd }}$ cooling & 10 & & & & & & \\
\hline $2^{\text {nd }}$ heating & 10 & $194.7 \rightarrow 265.3$ & 232.4 & 5.1 & $270.0 \rightarrow 288.5$ & 275.1 & 0.6 \\
\hline $3^{\text {rd }}$ cooling & 20 & & & & & & \\
\hline $3^{\text {rd }}$ heating & 10 & $194.7 \rightarrow 260.7$ & 240.4 & 3.0 & $260.7 \rightarrow 288.3$ & 272.4 & 0.7 \\
\hline
\end{tabular}

Two enthalpic modifications are observed in three different heating processes at $10 \mathrm{~K} / \mathrm{min}$. Increasing cooling rates have been used before each heating process.

The most important enthalpic variation, depicted as modification 1, occurs in all cases in approximately similar temperature intervals to those observed by ${ }^{2} \mathrm{H}$ NMR to correspond with changes in the structural water molecules motion along their wall sites (Table 1). The basic pore structure remains unaltered at these temperatures. This fact, added to the reversibility of the process (shown by the consecutive results with the same sample), identifies indeed modification 1 with changes in the structural water behavior. 
Another enthalpic change, modification 2, is observed around $0{ }^{\circ} \mathrm{C}$ with a lower $\Delta H^{o}$ value, related to fusion-freezing processes described for water confined in pores at these temperatures. ${ }^{7}$ In our case it corresponds with the presence of water mini-droplets inside the pore.

\subsection{DSC results for the compound of $( \pm) 2 \cdot 2 \mathrm{H}_{2} \underline{\mathrm{O}}$}

Table 2: Experiment performed on a $( \pm) \mathbf{2} \cdot 2 \mathrm{H}_{2} \mathrm{O}$ sample.

\begin{tabular}{|c|c|c|c|c|c|c|c|}
\hline process & $\begin{array}{c}\text { rate } \\
\mathrm{K} / \mathrm{min}\end{array}$ & \multicolumn{2}{|c|}{ modification 1 } & \multicolumn{3}{c|}{ modification 2 } \\
\hline & $\begin{array}{c}\text { temp.interval } \\
\mathrm{T} / \mathrm{K}\end{array}$ & $\begin{array}{c}T_{\text {peak }} \\
\mathrm{K}\end{array}$ & $\begin{array}{c}\Delta H^{\circ} \\
\mathrm{J} / \mathrm{g}\end{array}$ & $\begin{array}{c}\text { temp.interval } \\
T / \mathrm{K}\end{array}$ & $\begin{array}{c}T_{\text {peak }} \\
\mathrm{K}\end{array}$ & $\begin{array}{c}\Delta H^{\circ} \\
\mathrm{J} / \mathrm{g}\end{array}$ \\
\hline $1^{\text {st }}$ cooling & 5 & & & & & & \\
\hline $1^{\text {st }}$ heating & 10 & $196.8 \rightarrow 226.1$ & 201.6 & 2.6 & $257.7 \rightarrow 286.1$ & 267.3 & 1.6 \\
\hline $2^{\text {nd }}$ cooling & 10 & & & & & & \\
\hline $2^{\text {nd }}$ heating & 10 & $196.5 \rightarrow 224.2$ & 201.6 & 2.7 & $251.8 \rightarrow 295.7$ & 274.0 & 3.8 \\
\hline $3^{\text {rd }}$ cooling & 20 & & & & & & \\
\hline $3^{\text {rd }}$ heating & 10 & $202.2 \rightarrow 223.3$ & 207.4 & 0.5 & $257.6 \rightarrow 292.9$ & 270.6 & 2.7 \\
\hline
\end{tabular}

Again, two enthalpic modifications are observed in three different heating processes at $10 \mathrm{~K} / \mathrm{min}$. Increasing cooling rates have been used before each heating process.

When submitted to DSC experiments, equivalent modifications are observed and shown in Table 2. It can be noted that the temperature intervals are shorter in the case of modification 1.

\subsection{Loss of water content of $( \pm) \mathbf{1} \cdot 2 \mathrm{H}_{2} \underline{\mathrm{O} \text { and }( \pm) \mathbf{2} \cdot 2 \mathrm{H}_{2}} \underline{\mathrm{O} \text { observed by DSC and TG }}$}

For compound $( \pm) \mathbf{1} \cdot 2 \mathrm{H}_{2} \mathrm{O}$, DSC experiments in the temperature interval $283 \mathrm{~K}-363$ $\mathrm{K}$ were made at a heating rate of $10 \mathrm{~K} / \mathrm{min}$. Before being submitted to the heating process, the sample was equilibrated inside the calorimeter at $T=283 \mathrm{~K}$. Only one peak over the temperature range $326 \mathrm{~K}-364 \mathrm{~K}\left(T_{\text {peak }}=350.1 \mathrm{~K}\right)$, was observed, corresponding to a loss of mass of $13.6 \%$ for the sample. In order to study the reversibility of this process the sample was immediately submitted to a cooling and second heating runs under the same conditions and no thermal effect was found in any of the records, indicating that the thermal effect found in the first heating can be associated with the loss of two water molecules (theoretical mass loss, 13.0\%).

A similar phenomenon was also observed by DT/TGA measurements, in which the mass loss between $333 \mathrm{~K}-393 \mathrm{~K}$ results in a $13.7 \%$, again consistent with the loss of two water molecules.

\footnotetext{
${ }^{7}$ Höhne, G.W.H.; Hemminger, W.F.; Flammersheim, H.-J.; "Differential Scanning Calorimetry“, $2^{\text {nd }}$ edition, Springer, Berlin 2003, p. 229.
} 
The DSC measurements of compound $( \pm) 2 \cdot 2 \mathrm{H}_{2} \mathrm{O}$ in the interval $283 \mathrm{~K}-343 \mathrm{~K}$ show the dehydration endotherm over the temperature range $310 \mathrm{~K}-338 \mathrm{~K}\left(T_{\text {peak }}=\right.$ $329.4 \mathrm{~K}$ ), corresponding to a $11.7 \%$ of mass loss. The theoretical calculated value for the loss of two water molecules is $11.9 \%$, that is, in both compounds the relation water/monomer is $2 / 1$.

\subsection{Experimental}

\subsubsection{DSC Experiments}

The behavior of the sample as a function of the temperature was studied by Differential Scanning Calorimetry. Two DSC apparatus were used for the measurements. For experiments at lower temperatures (from $150 \mathrm{~K}$ to $298 \mathrm{~K}$ ) a Mettler DSC30 was used. For experiments made in the temperature interval $283 \mathrm{~K}$ to $363 \mathrm{~K}$ a Pyris1 instrument from Perkin Elmer was used. Both instruments were previously calibrated in temperature and energy with reference materials. ${ }^{8}$ The standards used for calibration were hexafluorobenzene, $99.9 \%$ purity, supplied by Aldrich; benzoic acid NIST standard reference sample 39j; and high-purity indium (mass fraction: > 0.99999) and tin supplied by Perkin-Elmer. In all the experiments the samples were examined in non hermetically sealed pans and in nitrogen atmosphere. Samples were weighed before and after the runs with a Mettler AT21 microbalance, sensitivity $\pm 0.000002 \mathrm{~g}$.

For the experiments at lower temperatures the sample was equilibrated inside the calorimeter at $T=298 \mathrm{~K}$ and then cooled at a rate of $5 \mathrm{~K} / \mathrm{min}$ until $150 \mathrm{~K}$. The cooled sample was afterwards subjected to a heating run at a rate of $10 \mathrm{~K} / \mathrm{min}$ and two broad peaks corresponding to two different processes (modifications) were found. In order to study the reversibility of the observed behavior and the influence of the rate of cooling, the sample was subjected to cooling at a rate of $10 \mathrm{~K} / \mathrm{min}$ followed by heating at 10 $\mathrm{K} / \mathrm{min}$, and newly cooled at a rate of $20 \mathrm{~K} / \mathrm{min}$ followed by a heating rate of $10 \mathrm{~K} / \mathrm{min}$. As the results are reproduced, the processes are reversible.

For the experiments in the temperature interval from $283 \mathrm{~K}$ to $363 \mathrm{~K}$ samples were equilibrated inside the calorimeter at $T=283 \mathrm{~K}$ before being submitted to the heating process. In order to study the reversibility of this process, samples were immediately

\footnotetext{
${ }^{8}$ (a) Gmelin, E.; Sarge, S.M. Thermochim. Acta, 2000, 347, 9-13. (b) Sarge, S.M.; Gmelin, E.; Höhne, G.W.H.; Cammenga, H.K.; Hemminger, W.; Eysel, W.; Thermochim. Acta. 1994, 247, 129-168. (c) GEFTA (Gesellschaft für Thermische Analyse, Germany), Gmelin, E.; Sarge, S.M. Pure Appl. Chem. 1995, 67, 1789-1800. (d) Sabbah, R.; Xu-wu, A.; Chickos, J.S.; Planas Leitão, M.L.; Roux, M.V.; Torres, L.A.; Thermochim. Acta, 1999, 331, 93-204.
} 
submitted to a cooling and a second heating runs under the same conditions and no thermal effect was found in any of the records, indicating that the thermal effect observed in the first heating was associated with the irreversible loss of water.

In the case of $( \pm) \mathbf{1} \cdot 2 \mathrm{H}_{2} \mathrm{O}$, the sample was kept in a box with a relative humidity of $92 \%$ over 50 days in order to study the possible reversibility of the process by introduction of water in the molecule. The weight of the sample and a new DSC run showed that the loss of water is irreversible.

\subsubsection{TG Experiments}

Experiments were carried out in a DSC Seiko calorimeter, with a TG/DTA 6200 thermogravimetry accessory. Non hermetically sealed aluminium pans were used for introducing $1.99087 \mathrm{mg}$ of $( \pm) \mathbf{1} \cdot 2 \mathrm{H}_{2} \mathrm{O}$. Results were obtained employing a heating rate of $5 \mathrm{~K} / \mathrm{min}$.

\section{Analytical Data for Compound $( \pm) 2 \cdot 2 \mathrm{H}_{2} \underline{\mathrm{O}}$}

\subsection{Experimental procedure and spectroscopic and physical data}

Compound 2 was synthesized by condensing the dilithium salt of 3-methylenecyclohexanecarboxylic acid with hepta-1,6-dien-4-one following the synthetic sequence reported for other members of this family of compounds. ${ }^{9}$ Single crystals of compound 2 suitable for X-ray analysis were grown at room temperature from a damp carbon tetrachloride/2,2,4-trimethylpentane mixture (4:1), after several days.

\section{$\left(1 R^{*}, 5 R^{*}\right)-7,7-D i a l l y l-5-h y d r o x y m e t h y l-6-o x a b i c y c l o[3.2 .1]$ octane-1-carboxylic}

Acid (2). Crystalline solid: $\mathrm{mp} 72.8-73.5{ }^{\circ} \mathrm{C} ; R_{f} 0.60$ (ethyl acetate); IR (KBr) $3732(\mathrm{w})$, 3390 (br), 3075 (m), 2959 (s), 2869 (m), 2641 (br), 2360 (s), 1670 (s), 1638 (m), 1434 (m), 1045 (s), 773 (s) cm ${ }^{-1} ;{ }^{1} \mathrm{H}$ NMR $\left(\mathrm{CDCl}_{3}, 500 \mathrm{MHz}\right) \delta 5.99$ (ddd, $J=10.0,7.0,7.0$ $\mathrm{Hz}, 1 \mathrm{H}), 5.89$ (ddd, $J=10.0,7.0,7.0 \mathrm{~Hz}, 1 \mathrm{H}), 5.15-5.02(\mathrm{~m}, 4 \mathrm{H}), 3.56$ (d, $J=11.8 \mathrm{~Hz}$, 1H), $3.42(\mathrm{~d}, J=11.8 \mathrm{~Hz}, 1 \mathrm{H}), 2.88(\mathrm{ddd}, J=12.0,2.5,2.5 \mathrm{~Hz}, 1 \mathrm{H}), 2.71$ (br d, $J=7.0$ Hz, 2H), 2.40 (br d, $J=7.0 \mathrm{~Hz}, 2 \mathrm{H}$ ), 2.30 (br ddd, $J=11.0,10.7,2.5 \mathrm{~Hz}, 1 \mathrm{H}$ ), 2.101.95 (m, 1H), 1.81-1.73 (m, 1H), 1.75-1.67 (m, 1H), 1.57 (br dd, $J=12.4,7.5 \mathrm{~Hz}, 1 \mathrm{H})$, $1.45(\mathrm{~d}, J=12.0 \mathrm{~Hz}, 1 \mathrm{H}), 1.29(\mathrm{ddd}, J=13.0,11.7,7.0 \mathrm{~Hz}, 1 \mathrm{H}) ;{ }^{13} \mathrm{C} \mathrm{NMR}\left(\mathrm{CDCl}_{3}\right.$, $125 \mathrm{MHz}) \delta 178.5,134.5,134.4,118.0,117.9,85.4,83.2,66.3,55.9,42.4,39.8,37.9$, 32.0, 31.2, 19.1. Anal. Calcd for $\mathrm{C}_{15} \mathrm{H}_{24} \mathrm{O}_{5}$ : C, 63.36; H, 8.51. Found: C, 63.42; H, 8.34.

\footnotetext{
${ }^{9}$ Carrasco, H; Foces-Foces, C.; Pérez, C.; Rodríguez, M.L.; Martín, J.D. J. Am. Chem. Soc. 2001, 123, 11970-11981.
} 


\subsection{Crystal structure data for $( \pm) 2 \cdot 2 \mathrm{H}_{2} \mathrm{O}$ at $170 \mathrm{~K}$}

(Further details of the data collection and structure solution of $( \pm) 2 \cdot 2 \mathrm{H}_{2} \mathrm{O}$ at 293,170 and $115 \mathrm{~K}$ are provided in CIF)

Crystal data and structure refinement parameters for $( \pm) 2 \cdot 2 \mathrm{H}_{2} \mathrm{O}$ at $170 \mathrm{~K}$

Identification code

Empirical formula

Formula weight

Temperature

Wavelength

Crystal system

Space group

Unit cell dimensions

Volume

$Z$

Density (calculated)

Absorption coefficient

F(000)

Theta range for data collection

Reflections collected

Completeness to theta $=27.50^{\circ}$

Refinement method

Final $R$ indices [I>2sigma(I)]

$R$ indices (all data)

Largest diff. peak and hole f231t

C15 H26 O6

302.36

170(2) K

$0.71073 \AA$

Trigonal (hexagonal axis)

R-3

$$
\begin{array}{ll}
\mathrm{a}=35.405(5) \AA & \alpha=90^{\circ} . \\
\mathrm{b}=35.405(5) \AA & \beta=90^{\circ} . \\
\mathrm{c}=6.6260(5) \AA & \gamma=120^{\circ} .
\end{array}
$$

7193.0(14) $\AA^{3}$

18

$$
\begin{aligned}
& 1.256 \mathrm{Mg} / \mathrm{m}^{3} \\
& 0.096 \mathrm{~mm}^{-1}
\end{aligned}
$$

2952

1.99 to $27.50^{\circ}$.

\section{2}

$99.0 \%$

Full-matrix least-squares on $\mathrm{F}^{2}$

$\mathrm{R} 1=0.0909, \mathrm{wR} 2=0.2387$

$\mathrm{R} 1=0.1128, \mathrm{wR} 2=0.2544$

1.479 and -0.285 e. $\AA^{-3}$ 
Table 3: $\quad( \pm) 2 \cdot 2 \mathrm{H}_{2} \mathrm{O}$ at $170 \mathrm{~K}$

\begin{tabular}{lc}
\hline $\mathrm{O}(6)-\mathrm{O}(6) \# 1$ & $2.697(9)$ \\
$\mathrm{O}(6)-\mathrm{O}(6) \# 2$ & $2.736(7)$ \\
$\mathrm{O}(6)-\mathrm{O}(6) \# 3$ & $2.736(7)$ \\
$\mathrm{O}(7)-\mathrm{O}(8) \# 4$ & $1.45(6)$ \\
$\mathrm{O}(7)-\mathrm{O}(8) \# 1$ & $1.45(6)$ \\
$\mathrm{O}(8)-\mathrm{O}(6) \# 2$ & $1.619(13)$ \\
$\mathrm{O}(8)-\mathrm{O}(8) \# 4$ & $2.90(11)$ \\
$\mathrm{O}(6) \# 1-\mathrm{O}(6)-\mathrm{O}(6) \# 2$ & 90.0 \\
$\mathrm{O}(6) \# 2-\mathrm{O}(6)-\mathrm{O}(6) \# 3$ & 60.0 \\
$\mathrm{O}(8) \# 4-\mathrm{O}(7)-\mathrm{O}(8) \# 1$ & 0.0 \\
$\mathrm{O}(8) \# 1-\mathrm{O}(7)-\mathrm{O}(8)$ & 180.0
\end{tabular}

Selected bond lengths $[\AA]$ and angles $\left[{ }^{\circ}\right]$ for the disorder water molecule inside the channel. Occupancy factors of $0.747(11), 0.178(12)$ and $0.079(9)$ for O6, O7 and O8 respectively. Symmetry transformations used to generate equivalent atoms: $\# 1 \mathrm{y}+1 / 3,-\mathrm{x}+\mathrm{y}+2 / 3,-\mathrm{z}-1 / 3 \quad \# 2-\mathrm{y}+1, \mathrm{x}-\mathrm{y}, \mathrm{z} \# 3-\mathrm{x}+\mathrm{y}+1,-\mathrm{x}+1, \mathrm{z}$ $\# 4-x+4 / 3,-y+2 / 3,-z-1 / 3$

Table 4: $( \pm) \mathbf{2} \cdot 2 \mathrm{H}_{2} \mathrm{O}$ at $170 \mathrm{~K}$. Selected torsion angles $\left[{ }^{\circ}\right]$ defining the conformation of the substituents

\begin{tabular}{lc}
\hline $\mathrm{C}(1)-\mathrm{C}(2)-\mathrm{C}(3)-\mathrm{C}(4)$ & $-39.0(4)$ \\
$\mathrm{C}(4)-\mathrm{C}(5)-\mathrm{C}(7)-\mathrm{O}(3)$ & $-50.1(4)$ \\
$\mathrm{C}(4)-\mathrm{C}(5)-\mathrm{C}(7)-\mathrm{O}(4)$ & $127.7(3)$ \\
$\mathrm{O}(1)-\mathrm{C}(1)-\mathrm{C}(8)-\mathrm{O}(2)$ & $55.4(4)$
\end{tabular}


Table 5: Hydrogen bonds for $( \pm) 2 \cdot 2 \mathrm{H}_{2} \mathrm{O}$ at $170 \mathrm{~K}\left[\AA\right.$ and $\left.^{\circ}\right]$.

\begin{tabular}{lcccc}
\hline D-H...A & d(D-H) & d(H...A) & $d(D . . A)$ & $<($ DHA $)$ \\
\hline $\mathrm{O}(2)-\mathrm{H}(2) \ldots \mathrm{O}(3) \# 6$ & 0.84 & 2.00 & $2.790(4)$ & 157 \\
$\mathrm{O}(4)-\mathrm{H}(4) \ldots \mathrm{O}(5) \# 7$ & 0.84 & 1.76 & $2.602(4)$ & 176 \\
$\mathrm{O}(5)-\mathrm{H}(5 \mathrm{WB}) \ldots \mathrm{O}(1)$ & $0.82(1)$ & $1.94(1)$ & $2.749(3)$ & $169(5)$ \\
$\mathrm{O}(5)-\mathrm{H}(5 \mathrm{WA}) \ldots \mathrm{O}(2) \# 8$ & $0.82(1)$ & $1.95(1)$ & $2.772(3)$ & $176(5)$ \\
\hline
\end{tabular}

Symmetry transformations used to generate equivalent atoms:

$\# 1 \mathrm{y}+1 / 3,-\mathrm{x}+\mathrm{y}+2 / 3,-\mathrm{z}-1 / 3$ \#2 -y+1,x-y,z \#3 -x+y+1,-x+1,z \#4 -x+4/3,-y+2/3,-z-1/3

$\# 5 x-y+1 / 3, x-1 / 3,-z-1 / 3 \quad \# 6 x-y+1 / 3, x-1 / 3,-z+2 / 3 \quad \# 7 y+1 / 3,-x+y+2 / 3,-z+2 / 3$

$\# 8 \mathrm{x}, \mathrm{y}, \mathrm{z}-1$

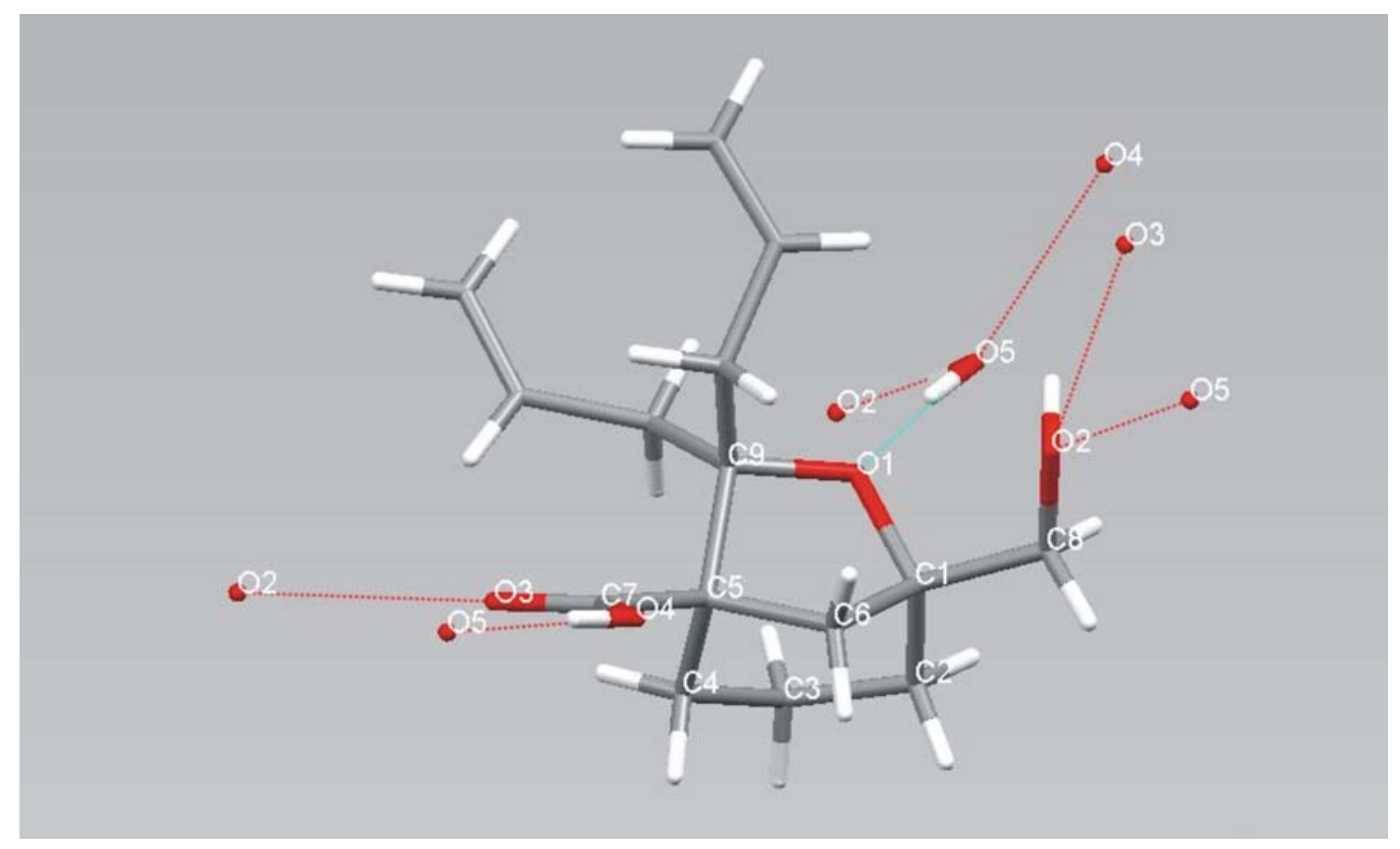

Figure 5: Molecular structure of compound $( \pm) 2 \cdot 2 \mathrm{H}_{2} \mathrm{O}$ at $170 \mathrm{~K}$ showing the numbering system and the $\mathrm{O}-\mathrm{H} . . . \mathrm{O}$ hydrogen interactions 


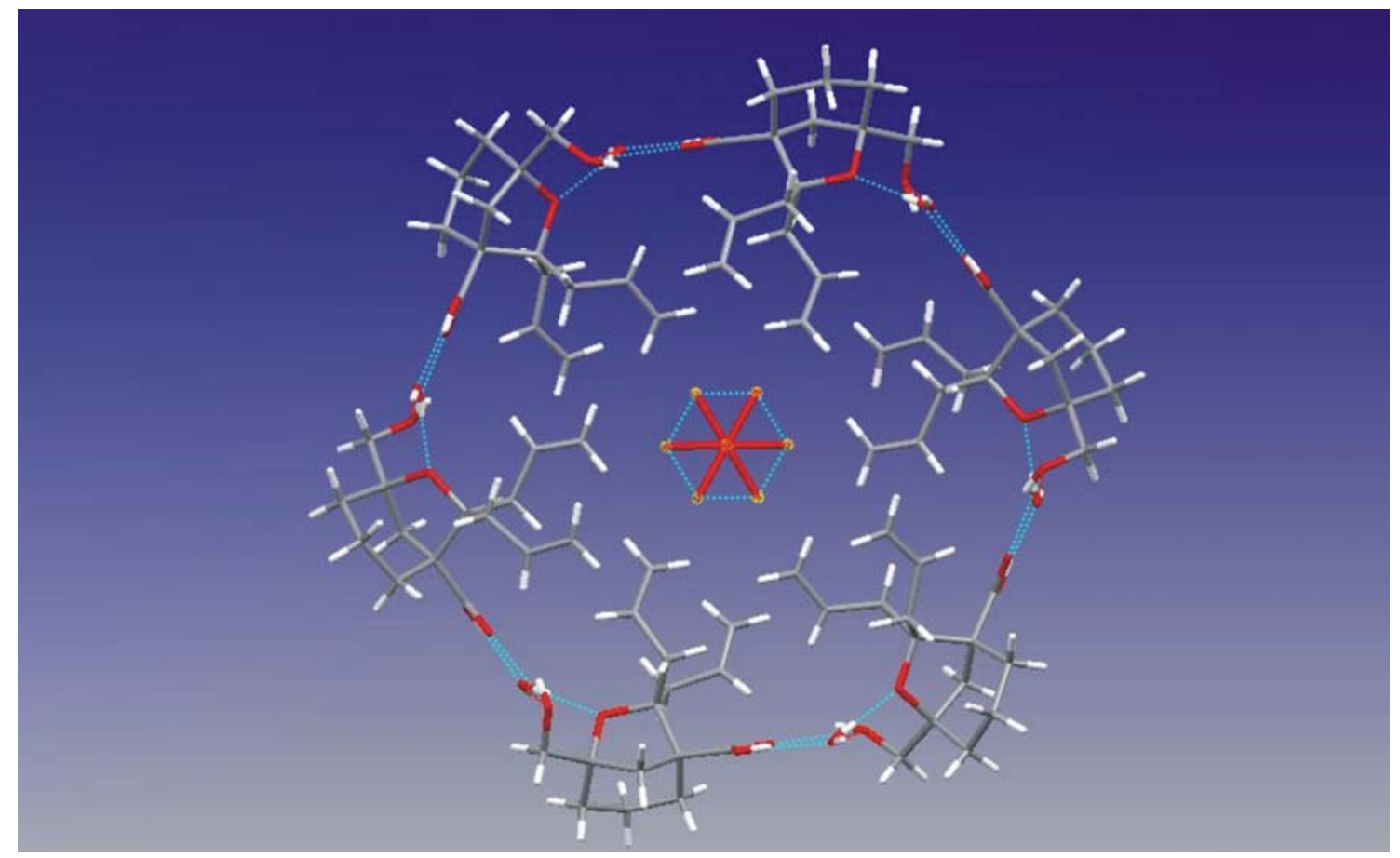

Figure 6: Macro-ring system $\left(( \pm) 2 \cdot 2 \mathrm{H}_{2} \mathrm{O}, 170 \mathrm{~K}\right)$ showing the hydrogen bonds and the disorder of the water molecule inside the channel.

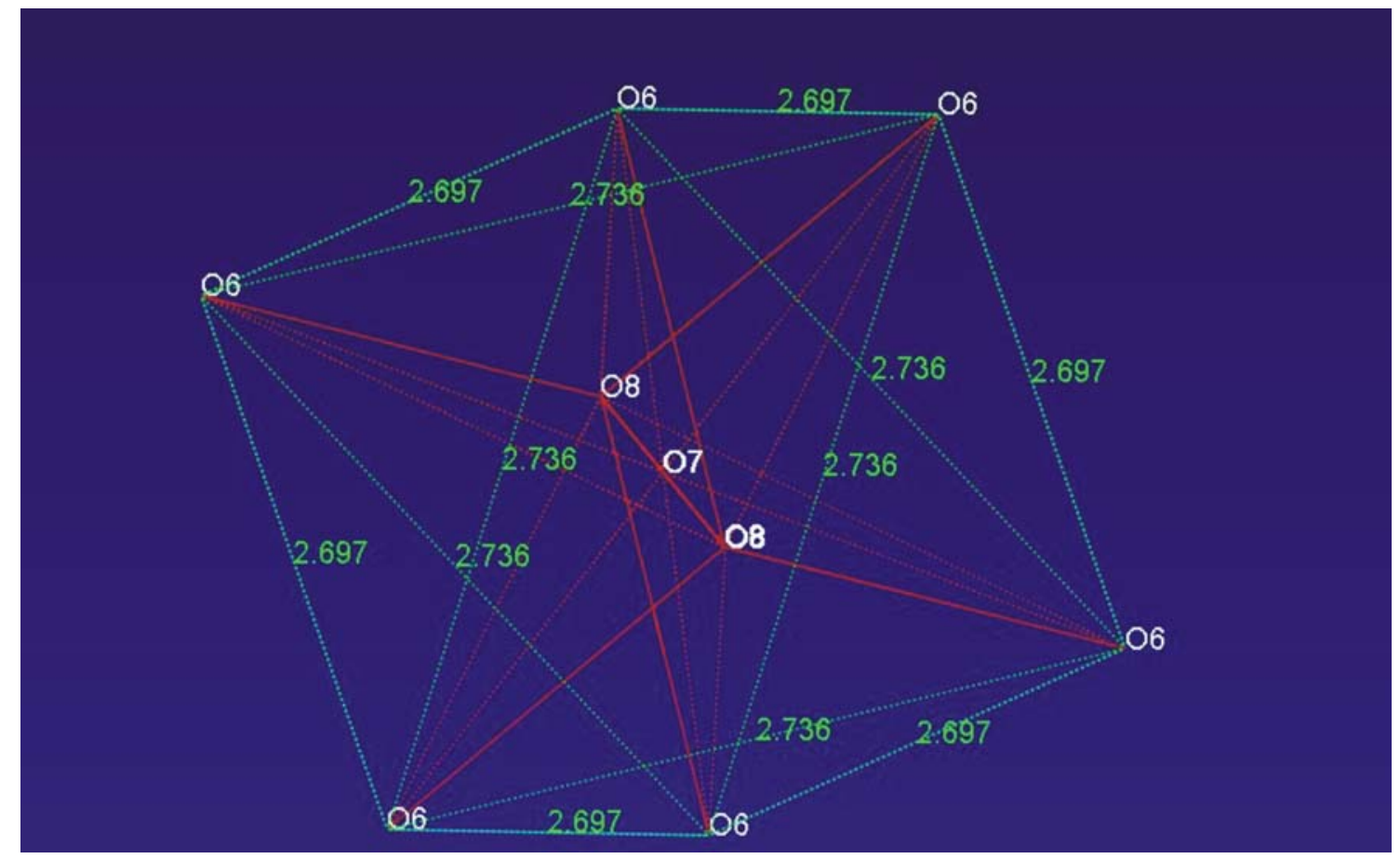

Figure 7: Disordered water molecule inside the channel $\left(( \pm) 2 \cdot 2 \mathrm{H}_{2} \mathrm{O}, 170 \mathrm{~K}\right)$ with occupancy factors of $0.747(11), 0.178(12)$ and $0.079(9)$ for $06, \mathrm{O} 7$ and $\mathrm{O} 8$ respectively. The bond distances for the disordered water molecule O6 forming the octahedral are also shown. 


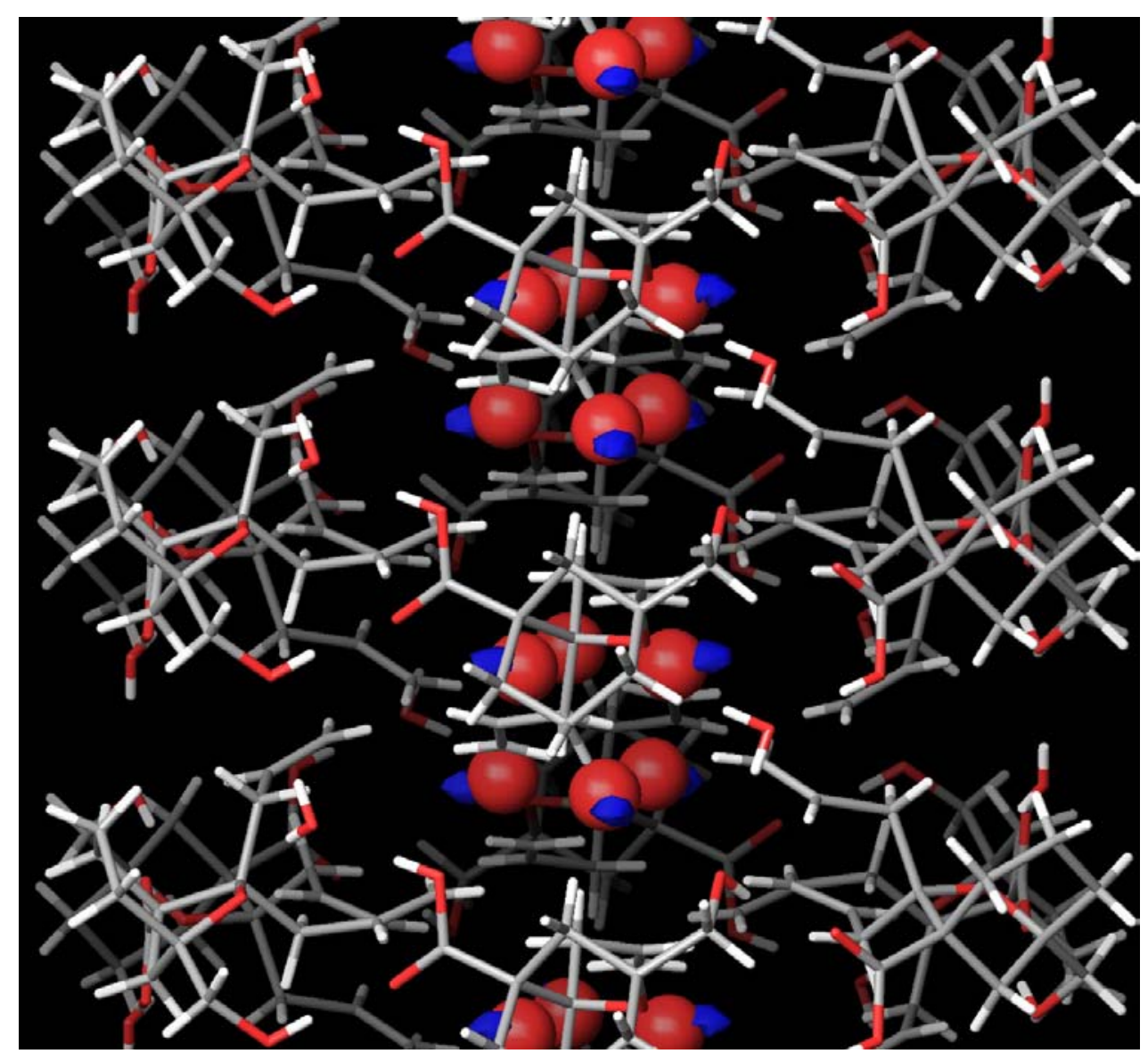

Figure 8: Location of discrete water clusters in the pore formed by $( \pm) 2 \cdot 2 \mathrm{H}_{2} \mathrm{O}$ (side view). Compound 2 and structural water in capped sticks, water molecules forming cage hexamers are shown as red spheres. Water-binding regions marked in blue (isosurface at $-2.2 \mathrm{kcal} / \mathrm{mol}$ level), were calculated using SiteMap as implemented in MAESTRO 7.5 ${ }^{10}$ (dipole method, $20 \AA$ atom cutoff, $0.25 \AA$ grid spacing). The availability of these hydrophilic nodes should reduce the energy barrier to water permeability across this otherwise predominantly hydrophobic pathway.

\footnotetext{
${ }^{10}$ MAESTRO, versión 7.5, Schrödinger, LLC, New York, 2005.
} 